\title{
DECAY OF SPRUCE IN THE MARITIME PROVINCES ${ }^{1}$ By A. G. DAVIDSON and D. R. REDMOND ${ }^{2}$
}

\begin{abstract}
Information on decay in 409 white, 653 red, and 51 black spruce was obtained at locations in the Maritime Provinces. Since the number of black spruce examined was small, this paper deals mainly with decay in white and red spruce. Gross and net volume tables are presented for white and red spruce in cubic feet and in board feet by age and diameter. The volume of decay in red spruce was less than in white spruce but, in both species, it was apparently not great enough to influence the selection of rotation ages based on the growth increments of individual trees. Butt decays were found to be more important than trunk decays in causing losses in both white and red spruce. The fungi producing white rots were the most important causes of both types of decay. Butt-decay fungi entered the trees mainly through the roots. Branch stubs were the most important infection courts for trunk-decaying fungi in white spruce, while in red spruce, wounds were as important as branch stubs. $A$ list of the fungi associated with decays in spruce is presented.
\end{abstract}

INTRODUCTION

During the period 1949 to 1951, living trees of white, Picea glauca (Moench) Voss, red, Picea rubens Sarg., and black, Picea mariana (Mill.) B.S.P., spruce were examined in the Maritime Provinces to obtain information on the causes and amount of decay. The number of black spruce examined, however, was small and this paper deals mainly with decay in white and red spruce.

\section{Location of Study AREas}

The studies of decay in white and black spruce were carried out at several localities in northern New Brunswick concurrently with a study of decay in balsam fir, while a separate study of decay in red spruce was conducted in the St. Margaret's Bay area of southern Nova Scotia. The locations of these study areas are shown in Fig. 1. The numbers of trees of each species examined in these areas are given in Table $I$.

TABLE I

The Number of Spruce by Species Examined in the Study Areas

\begin{tabular}{lrcc}
\hline \multicolumn{1}{c}{ Area } & wS & rS & bS \\
\hline Green River, N.B. & 250 & - & 15 \\
Popple Depot, N.B. & 106 & - & 21 \\
Jacquet River, N.B. & 17 & - & 15 \\
Budworm City, N.B. & 36 & - & - \\
St. Margaret's Bay, N.S. & - & $\mathbf{6 5 3}$ & - \\
\hline Total & 409 & $\mathbf{6 5 3}$ & 51 \\
\hline
\end{tabular}

${ }^{1}$ Contribution No. 381 from the Division of Forest Biology, Science Service, Department of Agriculture, Ottawa, Canada. Accepted for publication March 27, 1957.

${ }^{2}$ Forest Biology Laboratory, Fredericton, N.B. 


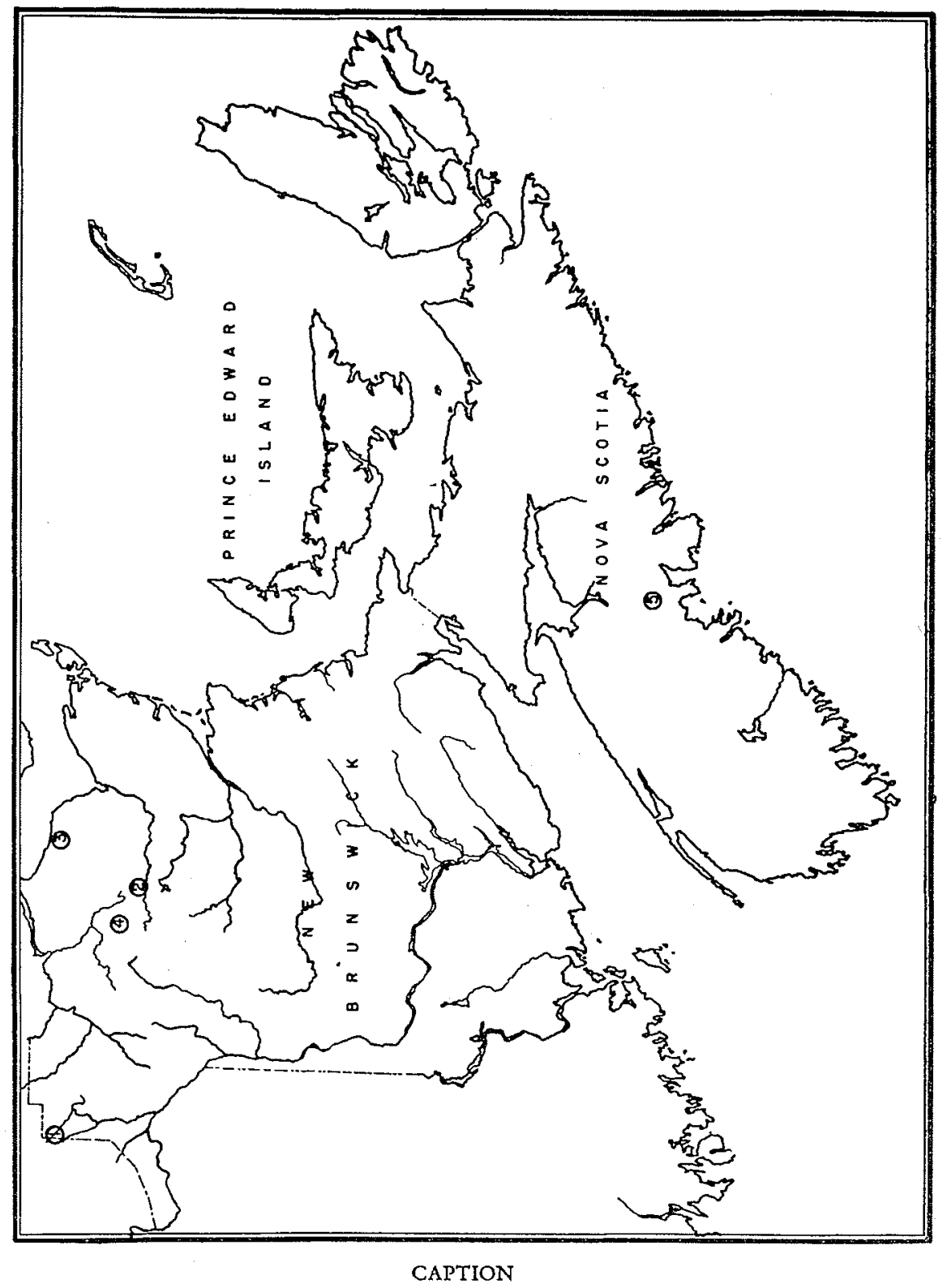

FIGURE 1. Map of the Maritime Provinces showing the location of the study areas for decay in spruce.

1-Green River, N.B.

2-Popple Depot, N.B.

3-Jacquet River, N.B.

4-Budworm City, N.B.

5-St. Margaret's Bay, N.S. 


\section{METHODS}

All spruce over 3 inches D.B.H. located in plots, that varied from 0.10 to 0.25 acre in area, were felled at a 1-foot stump and cut into 4-foot bolts to a 3-inch top. The diameter of the tree and of the decay were recorded at each cut. Bolts were sectioned further to determine the extent of disappearing decays.

A total age was estimated for each tree by adding to the stump age the average number of years required by seedlings in the area to reach the height of one foot. When the age at the stump could not be obtained because of decay, the stump age was estimated by adding to the age at the height, where obtained, the average number of years required by other trees on the plot to grow from stump height to that height.

No culling method was adopted for decay deductions in cubic feet, the decay losses presented being the actual volume of decayed wood. These volumes, together with the gross volumes, were determined by Smalian's

\section{TABLE II}

The Relationships Between Age, Gross Merchantable Volume, and Decay Volume in White and Red Spruce.

BasIS 407 AND 653 TREes RESPECTIVELY

(Curved Values)

\begin{tabular}{|c|c|c|c|c|c|c|c|c|}
\hline \multirow[t]{2}{*}{ Age } & \multicolumn{2}{|c|}{$\begin{array}{c}\text { Average Gross } \\
\text { Merchantable Volume } \\
\text { (Cu. ft.) }\end{array}$} & \multicolumn{2}{|c|}{$\begin{array}{l}\text { Average Decay } \\
\text { Volume } \\
\text { (Cu. ft.) }\end{array}$} & \multicolumn{2}{|c|}{$\begin{array}{c}\text { Average } \\
\text { Percentage of } \\
\text { Decay }\end{array}$} & \multicolumn{2}{|c|}{$\begin{array}{l}\text { Average Net } \\
\text { Merchantable } \\
\text { Vol. (Cu. ft.) }\end{array}$} \\
\hline & wS & rS & $\mathbf{w S}$ & rS & $\mathbf{w S}$ & rS & $\mathbf{w S}$ & rS \\
\hline 40 & 1.7 & - & 0.0 & - & 0.0 & - & 1.7 & - \\
\hline 50 & 2.3 & - & 0.0 & - & 0.0 & - & 2.3 & - \\
\hline 60 & 2.9 & - & 0.0 & 一 & 0.0 & - & 2.9 & - \\
\hline 70 & 3.5 & 1.0 & 0.0 & 0.0 & 0.0 & 0.0 & 3.5 & 1.0 \\
\hline 80 & 4.4 & 2.1 & 0.0 & 0.0 & 0.0 & 0.0 & 4.4 & 2.1 \\
\hline 90 & 5.6 & 3.4 & 0.0 & 0.0 & 0.0 & 0.0 & 5.6 & 3.4 \\
\hline 100 & 7.4 & 5.0 & 0.2 & 0.0 & 2.7 & 0.0 & 7.2 & 5.0 \\
\hline 110 & 10.0 & 6.8 & 0.5 & 0.1 & 5.0 & 1.5 & 9.5 & 6.7 \\
\hline 120 & 14.5 & 9.0 & 0.9 & 0.1 & 6.2 & 1.1 & 13.6 & 8.9 \\
\hline 130 & 21.9 & 11.5 & 1.4 & 0.1 & 6.4 & 1.0 & 20.5 & 11.4 \\
\hline 140 & 29.9 & 14.3 & 1.9 & 0.2 & 6.4 & 1.4 & 28.0 & 14.1 \\
\hline 150 & 36.3 & 17.2 & 2.4 & 0.2 & 6.6 & 1.2 & 33.9 & 17.0 \\
\hline 160 & 40.7 & 20.5 & 3.0 & 0.2 & 7.4 & 1.0 & 37.7 & 20.3 \\
\hline 170 & 43.7 & 23.8 & 3.5 & 0.2 & 8.0 & 0.8 & 40.2 & 23.6 \\
\hline 180 & 45.9 & 27.1 & 3.9 & 0.3 & 8.5 & 1.1 & 42.0 & 26.8 \\
\hline 190 & 47.1 & 30.1 & 4.2 & 0.3 & 8.9 & 1.0 & 42.9 & 29.8 \\
\hline 200 & 47.7 & 32.6 & 4.5 & 0.3 & 9.4 & 0.9 & 43.2 & 32.3 \\
\hline 210 & 一 & 34.4 & - & 0.3 & - & 0.9 & - & 34.1 \\
\hline 220 & - & 35.4 & 一 & 0.4 & - & 1.1 & - & 35.0 \\
\hline 230 & - & 35.6 & - & 0.4 & - & 1.1 & - & 35.2 \\
\hline
\end{tabular}


formula. Decay deductions in board feet, however, are expressed as cull. The trees were divided into 8-foot logs with the top log longer where necessary to bring the top diameter as near to 6 inches as possible. Only trees that contained at least one 8-foot $\log$ with a top diameter of 6 inches were considered merchantable. Gross board-foot volumes were determined from the New Brunswick Log Scale and cull volumes were calculated from the formula $D^{3} \times L^{3}{ }^{3}$ Any log having a cull volume equal to 50 per cent or more of the 15

gross volume was considered as a total cull log. In the sections dealing with quantitative measurements of decay losses, the terms "decay" and "cull" are used to designate the cubic-foot volume occupied by decay and the amount of cull in board feet, respectively.

\section{Decay in Relation to Age}

The relationships between age and decay volume and between age and cull volume are presented in Tables II and III respectively. The average

TABLE III

The Relationships Between Age, Gross Merchantable Volume, and Cull Volume in White and Red Spruce.

Basis 147 and 424 Trees ResPeCtively (Curved Values)

\begin{tabular}{|c|c|c|c|c|c|c|c|c|}
\hline \multirow[t]{2}{*}{ Age } & \multicolumn{2}{|c|}{$\begin{array}{c}\text { Average Gross } \\
\text { Merchantable Volume } \\
\text { (bd. ft.) }\end{array}$} & \multicolumn{2}{|c|}{$\begin{array}{l}\text { Average Cull } \\
\text { Volume } \\
\text { (bd. ft.) }\end{array}$} & \multicolumn{2}{|c|}{$\begin{array}{c}\text { Average } \\
\text { Percentage of } \\
\text { Cull }\end{array}$} & \multicolumn{2}{|c|}{$\begin{array}{l}\text { Average Net } \\
\text { Merchantable } \\
\text { Vol. (bd. ft.) }\end{array}$} \\
\hline & $w S$ & rS & $\mathbf{w S}$ & $\mathrm{rS}$ & $\mathbf{w S}$ & rS & & $\mathrm{rS}$ \\
\hline 40 & 21 & - & 0 & - & 0 & - & 21 & - \\
\hline 50 & 23 & - & 0 & - & 0 & - & 23 & - \\
\hline 60 & 25 & - & 0 & 一 & 0 & - & 25 & - \\
\hline 70 & 28 & - & 1 & - & 4 & - & 27 & — \\
\hline 80 & 32 & 42 & 2 & 0 & 6 & 0 & 30 & 42 \\
\hline 90 & 38 & 44 & 3 & 0 & 8 & 0 & 35 & 44 \\
\hline 100 & 49 & 46 & 5 & 0 & 10 & 0 & 44 & 46 \\
\hline 110 & 70 & 48 & 9 & 1 & 13 & 2 & 61 & 47 \\
\hline 120 & 102 & 55 & 16 & 1 & 16 & 2 & 86 & 54 \\
\hline 130 & 152 & 65 & 25 & 2 & 16 & 3 & 127 & 63 \\
\hline 140 & 187 & 81 & 36 & 2 & 19 & 2 & 151 & 79 \\
\hline 150 & 209 & 103 & 46 & 3 & 22 & 3 & 163 & 100 \\
\hline 160 & 222 & 128 & 50 & 6 & 22 & 5 & 172 & 122 \\
\hline 170 & 229 & 149 & 51 & 8 & 22 & 5 & 178 & 141 \\
\hline 180 & 235 & 162 & 50 & 8 & 21 & 5 & 185 & 154 \\
\hline 190 & 241 & 170 & 46 & 6 & 19 & 4 & 195 & 164 \\
\hline 200 & 246 & 175 & 40 & 5 & 16 & 3 & 206 & 170 \\
\hline 210 & - & 178 & - & 3 & - & 2 & - & 175 \\
\hline 220 & - & 180 & - & 2 & - & 1 & - & 178 \\
\hline
\end{tabular}

Where $\mathrm{D}=$ the largest decay diameter in inches. and $L=$ the extent of decay in feet. 
percentage of decay in white spruce increased from 2.7 per cent at 100 years to 9.4 per cent at 200 years. In red spruce, the amount of decay was considerably smaller and, although variable, never amounted to more than 1.5 per cent of the gross merchantable volume. The average age of the black spruce trees examined was 83 years and the average percentage of decay amounted to 2 per cent.

In white spruce, the percentage of cull in trees of merchantable size increased from 4 per cent at 70 years to 22 per cent at 150 to 170 years and decreased to 16 per cent at 200 years. Cull was again less in red spruce and never amounted to more than 5 per cent of the gross merchantable volume.

When the gross and net mean annual increments were determined, it was found that the maximum net mean annual increments of both species occurred at the same ages as the corresponding maximum gross mean annual increments. It would appear, therefore, that the volume of decay, as measured in this study, in living white and red spruce is not great enough in the areas sampled to be considered an important factor in the determination of rotation ages based on the growth increment of individual trees. The maximum gross mean annual increments in white spruce were obtained at 170 years (cubic-foot

TABLE IV

The Relationships Between Drameter, Gross Merchantable Volume, and Decay Volume in White and Red Spruce.

BASIS 409 AND 651 TREes RESPECTIVELY

(Curved Values)

\begin{tabular}{|c|c|c|c|c|c|c|c|c|}
\hline \multirow{2}{*}{$\begin{array}{r}\text { Me } \\
\text { D.B.H. } \\
\text { o.b. }\end{array}$} & \multicolumn{2}{|c|}{$\begin{array}{l}\text { Average Gross } \\
\text { rchantable Volume } \\
\text { (cu. ft.) }\end{array}$} & \multicolumn{2}{|c|}{$\begin{array}{l}\text { Average Decay } \\
\text { Volume } \\
\text { (cu. ft.) }\end{array}$} & \multicolumn{2}{|c|}{$\begin{array}{l}\text { Percentage of } \\
\text { Decay }\end{array}$} & \multicolumn{2}{|c|}{$\begin{array}{c}\text { Average Net } \\
\text { Merchantable } \\
\text { Vol. (Cu. ft.) }\end{array}$} \\
\hline & wS & rS & wS & rS & wS & rS & wS & rS \\
\hline 4 & 0.9 & 0.7 & 0.0 & 0.0 & 0.0 & 0.0 & 0.9 & 0.7 \\
\hline 5 & 1.8 & 2.0 & 0.0 & 0.0 & 0.0 & 0.0 & 1.8 & 2.0 \\
\hline 6 & 3.1 & 3.7 & 0.0 & 0.0 & 0.0 & 0.0 & 3.1 & 3.7 \\
\hline 7 & 4.8 & 5.7 & 0.1 & 0.0 & 2.1 & 0.0 & 4.7 & 5.7 \\
\hline 8 & 6.9 & 8.0 & 0.2 & 0.1 & 2.9 & 1.3 & 6.7 & 7.9 \\
\hline 9 & 9.3 & 10.8 & 0.3 & 0.1 & 3.2 & 0.9 & 9.0 & 10.7 \\
\hline 10 & 12.2 & 14.1 & 0.5 & 0.2 & 4.1 & 1.4 & 11.7 & 13.9 \\
\hline 11 & 16.0 & 17.6 & 0.7 & 0.2 & 4.4 & 1.1 & 15.3 & 17.4 \\
\hline 12 & 20.7 & 21.3 & 0.9 & 0.2 & 4.3 & 0.9 & 19.8 & 21.1 \\
\hline 13 & 26.1 & 25.4 & 1.3 & 0.3 & 5.0 & 1.2 & 24.8 & 25.1 \\
\hline 14 & 32.1 & 29.8 & 1.7 & 0.3 & 5.3 & 1.0 & 30.4 & 29.5 \\
\hline 15 & 38.3 & 34.7 & 2.0 & 0.3 & 5.2 & 0.9 & 36.3 & 34.4 \\
\hline 16 & 43.6 & 40.2 & 2.4 & 0.4 & 5.5 & 1.0 & 41.2 & 39.8 \\
\hline 17 & 48.5 & 45.9 & 3.2 & 0.4 & 6.6 & 0.9 & 45.3 & 45.5 \\
\hline 18 & 53.1 & 52.0 & 4.2 & 0.4 & 7.9 & 0.8 & 48.9 & 51.6 \\
\hline 19 & 57.6 & 58.4 & 5.3 & 0.5 & 9.2 & 0.9 & 52.3 & 57.9 \\
\hline 20 & 62.1 & 65.0 & 6.8 & 0.5 & 10.9 & 0.8 & 55.3 & 64.5 \\
\hline 21 & - & 72.7 & 一 & 3.5 & - & 4.8 & - & 68.2 \\
\hline
\end{tabular}


basis) and 160 years (board-foot basis). In red spruce, the corresponding gross increments were obtained at 210 and 200 years, respectively.

\section{Decay in Relation to Diameter}

The relationships between diameter and decay volume and between diameter and cull volume are shown in Tables IV and V, respectively. The percentage of decay in white spruce increased from 2.1 per cent in 7-inch trees to 10.9 per cent in 20 -inch trees. In red spruce, the percentage of decay never amounted to more than 1.4 per cent of the gross merchantable volume of trees 20 inches in diameter or smaller but increased to 4.8 per cent in 21-inch trees.

The percentage of cull in white spruce increased from 9 per cent in 8 -inch trees to 28 per cent in 20 -inch trees while, in red spruce, it never amounted to more than 4 per cent of the gross merchantable volume in any one diameter class.

\section{TABLE V}

The Relationships between Diameter, Gross Merchantable Volumes, and Cull Volume In White and Red Spruce.

Basis 171 and 423 Trees Respectively (Curved Values)

\begin{tabular}{|c|c|c|c|c|c|c|c|c|}
\hline \multicolumn{3}{|c|}{$\begin{array}{c}\text { Average Gross } \\
\text { Merchantable Volume } \\
\text { (bd. } \mathrm{ft}_{\text {. }} \text { ) }\end{array}$} & \multicolumn{2}{|c|}{$\begin{array}{l}\text { Average Cull } \\
\text { Volume } \\
\text { (bd. ft.) }\end{array}$} & \multicolumn{2}{|c|}{$\begin{array}{l}\text { Percentage of } \\
\text { Cull }\end{array}$} & \multicolumn{2}{|c|}{$\begin{array}{c}\text { Average Net } \\
\text { Merchantable } \\
\text { Vol. (bd. ft.) }\end{array}$} \\
\hline D.B.H.o.b. & wS & rS & wS & $\mathbf{r S}$ & wS & rS & $\mathbf{w S}$ & rS \\
\hline 7 & 6 & 10 & 0 & 0 & 0 & 0 & 6 & 10 \\
\hline 8 & 22 & 26 & 2 & 1 & 9 & 4 & 20 & 25 \\
\hline 9 & 42 & 44 & 6 & 1 & 14 & 2 & 36 & 43 \\
\hline 10 & 63 & 64 & 9 & 2 & 14 & 3 & 54 & 62 \\
\hline 11 & 84 & 87 & 14 & 2 & 17 & 2 & 70 & 85 \\
\hline 12 & 114 & 111 & 20 & 2 & 18 & 2 & 94 & 109 \\
\hline 13 & 143 & 138 & 29 & 3 & 20 & 2 & 114 & 135 \\
\hline 14 & 175 & 167 & 39 & 3 & 22 & 2 & 137 & 164 \\
\hline 15 & 210 & 197 & 48 & 4 & 23 & 2 & 162 & 193 \\
\hline 16 & 239 & 231 & 58 & 5 & 24 & 2 & 181 & 226 \\
\hline 17 & 270 & 265 & 68 & 6 & 25 & 2 & 202 & 259 \\
\hline 18 & 300 & 302 & 78 & 8 & 26 & 3 & 222 & 294 \\
\hline 19 & 327 & 339 & 88 & 10 & 27 & 3 & 239 & 329 \\
\hline 20 & 353 & 381 & 98 & 12 & 28 & 3 & 255 & 369 \\
\hline 21 & - & 425 & - & 14 & - & 3 & - & 411 \\
\hline
\end{tabular}

Relative IMPortance of THE TYPes of Decay

Butt decays ${ }^{4}$ were found to be more important than trunk decays in causing losses in both white and red spruce. Eighty, or 20 per cent, of the white spruce trees examined possessed decay deductions. ${ }^{5}$ Of these, 91 per

Decays with the largest decay diameter occurring at stump height.

${ }^{8}$ Decay deductions were made if the decay volume exceeded 0.05 cubic feet. 
cent possessed deductions for butt decay while 34 per cent possessed deductions for trunk decay. In red spruce, the corresponding percentages of the 117 (18 per cent of the number examined) trees with decay deductions were 55 per cent and 46 per cent respectively. In both species, butt decays were responsible for 72 per cent of the decay volume. Butt decays accounted for 95 per cent of the decay volume encountered in the black spruce trees examined.

\section{TABLE VI}

Frequency of Occurrence of Fungi Isolated From Decays in Spruce

\begin{tabular}{|c|c|c|c|}
\hline \multicolumn{4}{|l|}{ Butt Decays } \\
\hline White Rots & wS & IS & $\mathbf{b S}$ \\
\hline Armillaria mellea (Vahl ex Fries) Quel. & 1 & 1 & - \\
\hline Corticium galactinum (Fries) Burt & 10 & - & 3 \\
\hline Fomes pini (Thore) Lloyd & 3 & 2 & - \\
\hline Omphalia campanella Fries & 1 & 4 & - \\
\hline Peniophora gigantea (Fries) Massee & 1 & - & - \\
\hline Polyporous borealis Fries & 1 & 2 & - \\
\hline Polyporous tomentosus Fries & 7 & 5 & 5 \\
\hline Poria subacida (Peck) Sacc. & 1 & 10 & - \\
\hline Stereum sanguinolentum Alb. \& Schw. ex Fries & 1 & - & - \\
\hline \multirow[t]{2}{*}{ Stereum chailletii Pers. } & - & 1 & - \\
\hline & 26 & 25 & 8 \\
\hline \multicolumn{4}{|l|}{ Brown Rots } \\
\hline Coniophora puteana (Schum. ex. Fries) Karst. & 6 & - & 1 \\
\hline Merulius himantioides Fries & 1 & - & - \\
\hline Polyporous balsameus Peck & 3 & - & - \\
\hline \multirow[t]{2}{*}{ Polyporous schweinitzii Fries } & 2 & 一 & - \\
\hline & 12 & 0 & 1 \\
\hline \multicolumn{4}{|l|}{ Trunk Decays } \\
\hline White Rots & wS & IS & bS \\
\hline Fomes pini (Thore) Lloyd & 8 & 9 & - \\
\hline Omphalia campanella Fries & 1 & - & - \\
\hline Peniophora septentrionalis Laurila & - & 1 & - \\
\hline Polyporous abietinus Dicks. ex Fries & - & 1 & - \\
\hline \multirow[t]{2}{*}{ Stereum sanguinolentum Alb. \& Schw. ex Fries } & 7 & 3 & 1 \\
\hline & 16 & 14 & 1 \\
\hline \multirow{4}{*}{$\begin{array}{l}\text { Brown Rots } \\
\text { Fomes roseus (Alb. \& Schw. ex Fries) Cooke } \\
\text { Lenzites saepiaria Wulf. ex Fries }\end{array}$} & & & \\
\hline & 一 & 1 & - \\
\hline & 一 & 1 & - \\
\hline & 0 & 2 & 0 \\
\hline
\end{tabular}

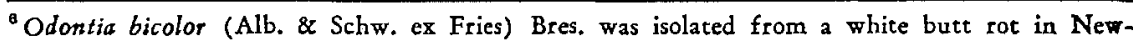
foundland. 
White rots were more important than brown rots in causing decay losses in both white and red spruce. Approximately 80 per cent of the butt decay infections in white spruce and over 90 per cent of these infections in red spruce were caused by fungi producing white rots. Practically all the trunk decay in both species was caused by these fungi.

\section{Infection Courts of the Fungi Causing Decay}

Butt-decaying fungi entered both white and red spruce mainly through the roots. Branch stubs were the most important infection courts for trunkdecaying fungi in white spruce while, in red spruce, wounds and branch stubs were of about equal importance.

\section{Fungr Isolated From Decays}

Table VI gives the frequency with which fungi were isolated from decays in spruce. Corticium galactinum (Fries) Burt and Polyporous tomentosus Fries were the fungi most frequently isolated from white butt rots in white spruce while Poria subacida (Peck) Sacc. and Polyporous tomentosus were isolated most frequently from white butt rots in red spruce. Coniophora puteana (Schum. ex Fries) Karst. was the fungus obtained most frequently from brown butt rots in white spruce. No successful isolations were made from the brown rots occurring in the butts of red spruce.

In a study of decay in subalpine spruce," Flammula connissans Fries was the second most frequently isolated fungus from white butt rots. Although this fungus has been isolated from yellow birch in the Maritime Provinces, it was not obtained during the present study. Conversely, Corticium galactinum and Poria subacida were not encountered in the subalpine spruce study.

Fomes pini (Thore) Lloyd and Stereum sanguinolentum Alb. \& Schw. ex Fries appeared to be the most common causes of trunk decay in both species of spruce.

\section{ACKNOWLEDGEMENTS}

The authors are indebted to Dr. D. E. Etheridge and Mr. J. T. B. Kingston for conducting the field work on red spruce and to Dr. M. K. Nobles and her staff, Botany and Plant Pathology, Science Service, Department of Agriculture, Ottawa, for the identifications of cultures of wood-decaying fungi. Thanks are also due to the officers of the several paper companies on whose limits the studies were carried out.

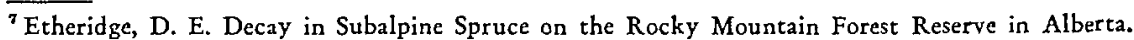
Can. Jour. Bot. 34: 305-816. 1956.

${ }^{8}$ Annual Report, Forest Insect and Disease Survey, Forest Biology Division, Science Service, Department of Agriculture, Ottawa, Canada. 1952.
} 